\title{
蝸牛・前庭神経刺激による脳幹反応
}

\author{
愛媛大学医学部耳鼻咽喉科学教室（主任：柳原尚明教授） \\ 暁清 文, 柳原尚明
}

\section{1. 緒咅}

難聴者つ螖牛を䉓気刺激することによって㯖覚を与 えようとする cochlear implant の試みは，現在のと ころその発展段階てあり日常会話を理解させるという 最終目標ては到造していない。 cochlear implant 沉は 多くの問題点があるが，そのうちであ最あ重要かつ困 難な点はいがうて電気刺激により適切な周波数情報 を聴神経法達するかということにある。一対の刺激 電極を用いる single channel system では lip-reading の補助として役だつか, warning signal が分るとすぎ ないことが明らかにされて㧍り ${ }^{9)}$ ，現在では multichannel system が開発され多くの研究施設で試作・ 実験が扣こなわれている410)。

さて, cochlear implant が実際に人間飞応用され目 的上する効果が得られるようになるまでには動物実験 に颃いて十分にその基礎的研究がなされる必要があ る。しかし動物実験に括いては組織学的研究は容易飞 できるものの，動物がどのような音を聞いているかは 人間には分らず，ここに動物実験の難しさがある。従 って動物が聴喾を得た時飞それを他覚的飞証明する方 法が必要となる。

このような観点から著者は聴性脳幹反応 (Auditory Brainstem Response: BSR) の技法を応用し，蝸牛 電気刺激によって生ず動る物の聴覚の指標として脳幹 反応を用いる方法を発表した

今回はこのような蝸牛刺激で得られた反応が確実に 聴神経の刺激によって誘発された反応であることを確 認するため, 聴神経, 前庭神経, 顔面神経を個別飞電 気刺激し, 得られた反応の此較検討を拈こなった。

\section{2. 実験方法}

実験動物にはプライエル反射正常の白色成熟モルモ ット 8 匹 (500-950g) を用いた。動物の麻酤はイソゾ ール (thiamylal sodium, $25-35 \mathrm{mg} / \mathrm{kg}$ ) 腹腔内注射 による全身麻醇と $0.5 \%$ キシロカインによる局所浸潤 麻酔を併用した。腹臥位にて頭部を固定後, 頭頂部の
皮覤を切開・剝離し， $8 \mathrm{~mm}$ 間隔で頭頂骨の正中線上 に2つの小孔を開けた。この小孔より銀ボール電極を 硬膜面飞㨂入して固定，脳幹反応の記録電極とした。

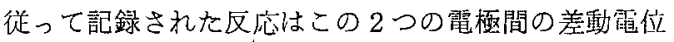
を表わしている。この電極より記録された反応は300$3,000 \mathrm{~Hz}$ の带域フィルタを通して增幅し, 図 1 亿示 す block-diagram に従って加算処理を扣こなった。

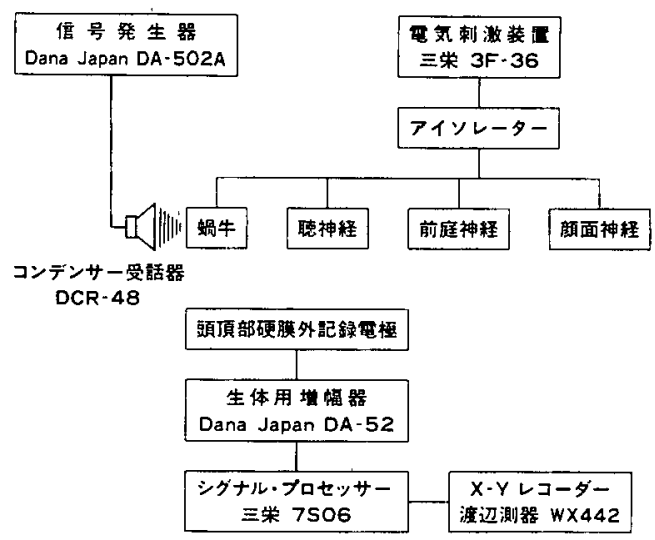

図 1 実験装置の block-diagram。実験は(1)音刺 激, (2)蝸牛電気刺激, (3)㯖神経刺激, (4)顔面 神経刺激, (5)前庭神経刺激の順でおこない, 反応の記録条件はどの場合も同一とした。す なわち，加算回数，操り返し時間，掃引時 間，增幅度は一定とした。

まず音刺激による脳幹反応を記録した。次に耳゙後法 により耳胞を開放し，手術顕微鏡下に耳小骨を除去し て螖牛を直視下沉扣いた。さらに1つの刺激雪極を第 3 回転側壁飞開けた小孔を通して中央階に扎き， る 1つの電極は正円空を通して鼓室階に执いた。これら 2 本の刺激電極汇より蝸牛霆気刺激を扣こない反忘を 記録した。この際，刺激電極には先端を電気研磨によ り尖らせ, 先端を除いてェナメルコーティングを施し た $0.1 \mathrm{~mm}$ 径のタングステン線を用いた。

次に蝸牛骨壁を除去し, 注意深く modiolusを形成 する骨を取り除いて聴神経を露出した。この聴神経を 
$0.3 \mathrm{~mm}$ 径の銀線を用いて電気刺激しそ施応を記録 した。また，顔面神経は錐体部で，前庭神経は内耳道 入口部でそれぞれ露出し, 聴神経の場合と同様の方法 で神経全体が刺激されるように注意しながら電気刺激 を招こなった。な扮記録はすべて同一条件となるよう にした。すなわち記録の㩧引時間, 增幅度, 加算回数 はいずれの場合も同一とし，それぞれの比較を容易に した。

音刺激は $4 \mathrm{kHz}, 0.3 \mathrm{msec}$ のクリック音を鼓膜か ら $5 \mathrm{~cm}$ のところに設置したコンデンサ受話器より 与えた。この際, 信号発生器の出力が $105 \mathrm{~dB}$ SPL の 時を $0 \mathrm{~dB}$ と規定した。電気刺激には $0.03 \mathrm{msec} の$ 矩 型波を用いた。音刺激の場合も電気刺激の場合む刺激 間隔は $80 \mathrm{msec} と し ，$ 得られた反応は前述の filter を 通して増幅し 加算処理を扮こなった。”掃引時間は 8 $\mathrm{msec}$, 加算回数は 600 回とした。反応はすべて 2 回記 録し，その結果は double trace で表方した。

な招記録した脳幹反応のうち，音刺激返応の

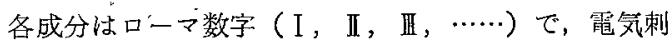
激䏓るるのはアラビア数字 $(1,2,3, \cdots \cdots)$ で表 現した。

\section{3. 結 果}

図 2 は正常モルモットの聴性脳幹反応である。従

dB SPL

0

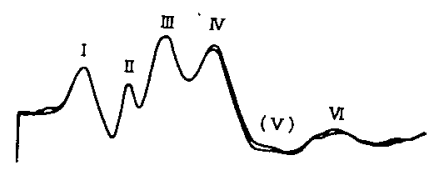

$-10$
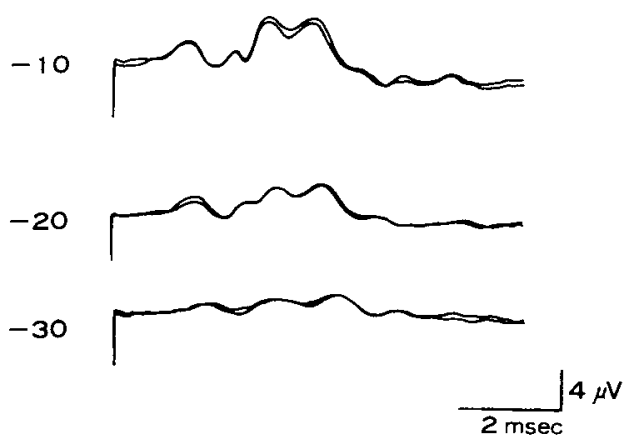

図 2 正常モルモットの聴性脳幹反応。 I-N 波 は振幅が大きく安定した反応であるが，V・ り波は低電位の不安定な反応である。
来の報告と記録法が異なるため若干反応波形は異なっ ているが，I～N 波までの振幅の大きな安定した反応 と，低電位で不安定なV，江波がみられた。

同じ実験動物を用いた蝸牛電気刺激（第 3 回転中央 階一基底回転鼓室階）飞よる反応の結果を 図 3 亿示 した。刺激矩形波の極性を（a）鼓室階側が陰性，(b) 中央階側が陰性，とした時の反応を示している。刺激 の極性とは関係なく 5 6 相性の 反応がみられ，その うちでも第 4 波は最も振幅も大きく安定していた。刺 激のアーチファクトが非常に大きいのであるいは短潜 時の反応がその中混入しているかもしれないが，音 刺激の VI波飞相当すると思われる 4 波が明確飞認めら れたので，これを指標として他の波形を決定した。こ の際，電気刺激による反応の潜時は，音刺激が内耳へ 伝達するの㴗する時間を考虑に入れても，音刺激の それよりあ短かいあのであった。

図 4 は聴神経の電気刺激炕よる反応である。4 波 は蛧牛刺激の場合と同㥞明嘹な波形が婄められたが， 1 波は刺激のアーチファクト飞混入したためか認めら れず，また $2 ， 3$ 波は波形が重なっていた。いずれに せよ聴神経刺激により蝩牛刺激の場合と類似の反応パ ターンが得られたが，4波を指標としてその潜時を比 較すると前者の方がわずか短かかった。

図 5 の前庭神経刺激炕よる反応は biphasicな波形 を示し，音刺激や蝸牛括よび聴神経の雪気刺激によっ て誘発される反応とは全く異なっていた。一方，顔面

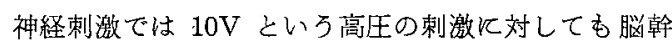
反応は誘発されなかった。

\section{4. 考按}

聴性脳幹反応 (ABR) の各成分の起源飞ついては, 第 I 波が聴神経の活動電位であることが認められてい る以外は確定して扔らず，現在議諭のあるところであ $る^{122)}$ 。ABR の反応成分を聴堂路の特定の神経の活動 電位之結びつけて考光る局在説 3388 ああるが, 反忘成 分と神経との対忘関係については報告者により必ずし も一致していない。一方，この反応成分は特定の神経 核や中継路の活動電位を反映したものではなく種々の 反応霞位が重なったものだとする説》も有力である。 ABR の特徵の 1 つは深い睡眠や麻酔中でさ元も反応 が比較的安定して記録できることで，臨床的には脳幹 障害の診断や乳幼児聴力検查飞扔いてその威力を発揮 している。

ところでモルモットの ABR は5 6 相性の反応か 


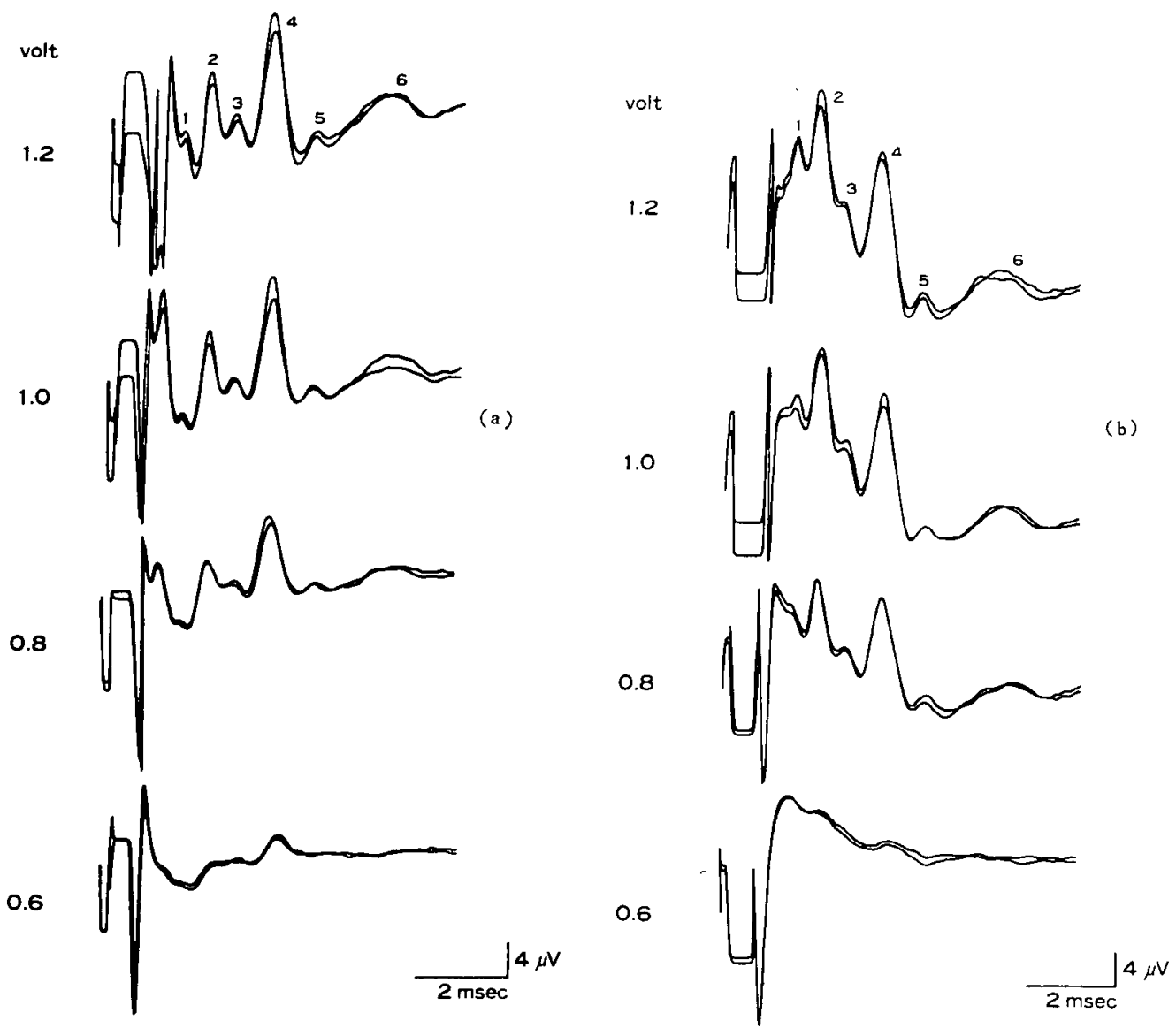

図 3 蛤牛電気刺激に上る脳幹反忘。第 3 回転中央階一基底回転鼓室階にそれぞれ電極を挿入 し，双極性江電気刺激を招こなった。刺激矩形波の極性を（a）鼓室階側が陰性，（b） 中央階側が陰性とした時の反応を示している。刺激の極性とは関係なく $5 \sim 6$ 相性の反応 が記録された。このうち第 4 波は最も振幅の大きな安定した反応であった。

らなり，人間の反応とは少し異なる。ネコの場合と同 様，モルモットに招いてもABR の反応成分のうちI 一N 波は 振幅の大きな安定した反応である。とりわけ VN 波は最も振幅が大きく弱い刺激や高頻度の刺激に上 っても誘発されることから，人間飞抢けるV波汇相当 するのではないかと考兄られている2)。な据 I-N波 は麻酔や体温の変化飞対しても比較的安定した反応で あるが，V，V波江潹麻醉時や低体温下では誘発し難く

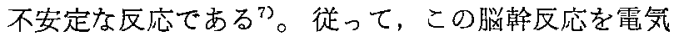
刺激汇よる聴党反応の指標とする立場からは， I - N 波のうちでも最も振幅が大きく安定しているN 波を指 標とするのが適切かと思われる。しかし螖牛電気刺激 によって誘発される脳幹反応についてはいまだほとん ど研究されて扔らず，電気刺激返応の各成分が
音刺激によるそれと1：1亿対応するか否かはさらに 実験を重ねて検討する必要がある。

今回の実験で朋らかとなったことは (1) 聴神経の刺 激汇上り蝸牛刺激の場合之類似の反応が誘発された。

(2) 前庭神経刺激では 反応持続時間の短かい biphasic な反応が誘発された。(3) 顔面神経刺激に上っては 脳幹反応恃誘発されなかった，などである。

従って螪牛刺激炕より聴神経が刺激されているのは 確かであるが，同時汇前庭神経が刺激されたとしても

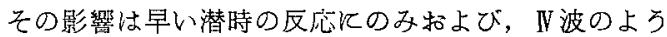
な少し潜時の荤い反応炕は影響しない。現在のところ これら前庭神経刺激と聴神経刺激㳊よる反応を分離す ることは far-field response を記録する限り不可能と 思われるが， filter の工夫等その道は残されている。 
volt

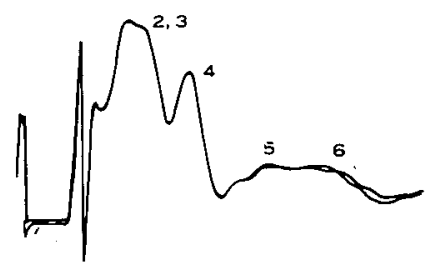

1.2

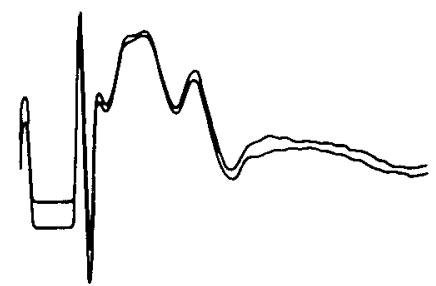

1.0

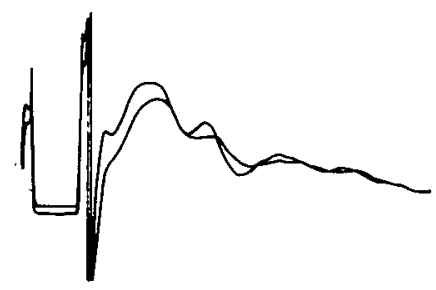

0.8

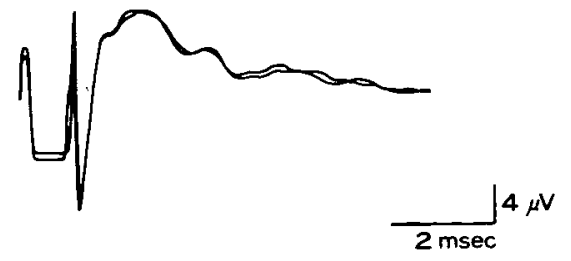

図 4 聴神経の電気刺激飞よる脳幹反応。第 2,3 波は波形が重なっていたが，第 4 波 は明確な反応として認められた。

しかし上述の理由に上り聴覚系の反応は V波を指標と すればその確認は可能である。

長期植込み実験の結果からも，一旦電極を固定さ光 すれば動物の麻醉や固定を考虑しなくても反応が記録 できることから，脸幹反応を聴覚反応の指標とする方 法はとりわけ cochlear implant の長期実験飞適して いる。しかし, 脳幹反応の反応波形自身には周波数特 異性はないので本法によって frequency coding の問 題は解決されず，その成果を過剩評価はできない。

ところで, 最近 Chouard. ららは人間飞括いて正円 空の電気刺澈汒上る脳幹反応を記録している。彼らは cochlear implant の適応をより客観的に決定する目的 で本法を抗こなっているが，正常者と難聴者ではその 反応波形は全く異なっていたという。反応波形と障害 の程度や原因が関係しているのか否か牥不明であるが volt

2.5

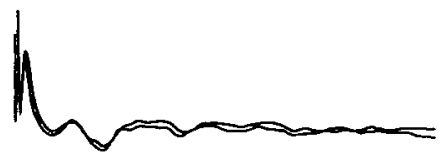

2.0

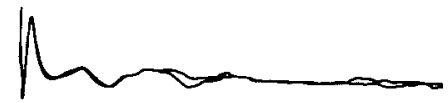

1.5

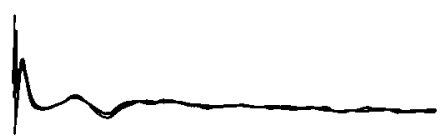

10

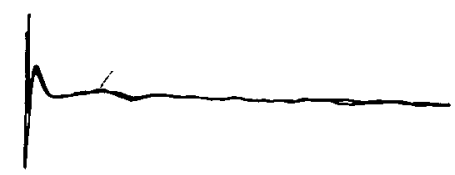

図 5 前庭神経刺激汅よる脳幹反心。聴神経 刺激の場合とは異なり；持続時間の短か いbiphasicな反応がみられた。

舆味ある問題である。

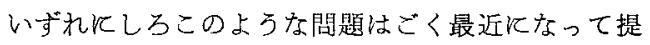
示されてきたことで，さらと組織だった研究が必要と 思われる。

\section{5. まとめ}

モルモットを用い，音刺激と蝸牛電気刺激によって 生ずる脳幹反応を比較した。さらに，この蝸牛刺激に よる反応が確実に㜇神経の剩激によって誘発された反 心であることを確認するため, 聴神経, 前庭神経, 顔 面神経をそれぞれ個別汇電気刺激し，得られた反応を 此較検討した。その結果, 蝸牛電気刺激によっても德 神経刺激によっても音刺激の場合と類似の $5 \sim 6$ 相性 の反応が得られた。いずれの反応にも共通しているこ とは第 4 波の振幅が最も大きく弱い刺激に打いても安 定してい它ことである。一方, 前庭神経刺激によって は持続時間の短かい biphasic な反応が誘発され，聴 神経刺激の場合とは全く買なっていた。また, 顔面神

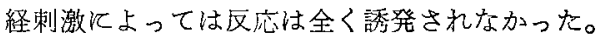


Brain Stem Responses Evoked by Cochlear and Vestibular Nerve Stimulation

Kiyofumi Gyo \& Naoaki Yanagihara

(Department of Otolaryngology, School of

Medicine, Ehime University)

(Director: Prof. N. Yanagihara)

Electrically and acoustically evoked brain stem responses were compared in guinea pigs. Electrical stimulation of the cochlea was made by two electrodes, one to the scala tympani of the basal turn, and the other to the scala media of the third turn. Six hundred consecutive responses were averaged by a computer. Responses evoked by the direct stimulations of the cochlear, vestibular and facial nerves were respectively recorded by the same procedure.

Electrical stimulation of the cochlea could evoke a response with successive five to six waves within $8 \mathrm{msec}$, of which the fourth wave was most prominent and stable. This response was similar to that one elicited by auditory stimuli. Direct stimulation of the cochlear nerve could evoke the same pattern of the response. On the other hand, stimulations of the vestibular and facial nerves could evoke definitely different responses, or even could evoke nothing.

参 考 文 献

1）安藤一郎: BSR の実験的研究. Audiology Japan, 20; 210-220, 1977.

2）安藤一郎：内耳神経切断尤る BSR の変化.
Audiology Japan, 20; 733-736, 1977.

3) Buchwald, J. S. and Huang, C.: Far-field acoustic response: origins in the cat. Science, 189; 382-384, 1975.

4) Burian, K., et al.: Designing and experience with multichannel cochlear implants. Acta Otolaryngol., 87; 190-195, 1979.

5) Chouard, C.H., Meyer, B., and Donadieu, F.: Auditory brainstem potentials in man evoked by electrical stimulation of the round window. Acta Otolaryngol., 87; 287-293, 1979.

6）暁 清文：正常ならびそカナマイ 難聴モルモット 飞扮ける聴性拈よび䉓気性脳幹反応. 日耳鼻，82; 1-10, 1979.

7) Jewett, 'D. L.: Volume conducted potentials in response to auditory stimuli as detected by averaging in the cat. Electroencephalogr. Clin. Neurophysiol., 25; 609-618, 1970.

8) Lev, A. and Sohmer, H.: Sources of averaged neural responses recorded in animal and human subjects during cochlear audiometry (electrocochleogram). Arch. Klin. Exp. Ohren Nasen Kehlkopfheilk., 201; 79-90, 1972.

9) Schindler, R.A., et al.: Multielectrode intracochlear implants. Arch. Otolaryngol., 103; 691-699, 1977.

10) Simmons, F.B., et al.: A functioning multichannel auditory nerve stimulator. Acta Otolaryngol., 87; 170-175, 1979.

（受付 54.7.26） 